\title{
Dialogue
}

Losing Oceania to the Pacific and the World DAVID HANLON

The Contemporary Pacific, Volume 29, Number 2, 285-3I 8

(C) 2017 by University of Hawai' $i$ Press 


\section{Losing Oceania to the Pacific \\ and the World}

\section{David Hanlon}

\section{G}

stone into a deep well and waiting for the splash." No, the friend replied writing "is like dropping a rose petal into the Grand Canyon and waiting for the bang" (Dening I998, xx). Back in 2000, at the University of Hawai'i conference celebrating the fiftieth anniversary of the Center for Pacific Islands Studies, Vince Diaz helped me endure the wait by putting images and passages from my book Upon a Stone Altar (1988) onto a T-shirt. It was splash enough for me in the days before Facebook and other forms of instantaneous social media. We lost Greg in March of 2008. Vince is still very much with us, though. I cite both as sources of inspiration for this essay on the larger scholarly world's recent rediscovery of the Pacific and what I see as the persisting need for the recovery of deeper Oceanic pasts made even more necessary by the omissions of an increasingly prominent Pacific Worlds approach. In making this argument, I share Teresia Teaiwa's distinction between the terms Pacific and Oceania (2008). The Pacific evokes outlander visions of the region, while Oceania, drawing on the works of Epeli Hau'ofa and Albert Wendt, represents the area as vast, diverse, fluid, and complex. ${ }^{1}$ These latter features require a more indigenously focused and conceptualized history. Putting aside for the time being a consideration of archaeological and comparative linguistic evidence, I look to imagination, discursive flourish, and Deep Time as integral methodologies in this recovery-a recovery transcending the limiting focus on contact, cross-cultural encounters, and colonization that continue to dominate much Pacific history. Such a tripartite approach, I believe, contributes to the emergence or reemergence of indigenous histories and indigenous historical practices in Oceania.

The Contemporary Pacific, Volume 29, Number 2, 286-3 I 8

(C) 2017 by University of Hawai' $i$ Press 


\section{The Rediscovery of the Pacific}

As Adrian Muckle has noted, there has been a "developing concern" of late to bring Pacific history into constructive conversation "with transnational/global/world history" $\left(20 \mathrm{I}_{5}, 229\right)$. A prime example of this effort is David Armitage and Alison Bashford's Pacific Histories: Ocean, Land, People (2014). This edited volume seeks to join the history of Oceania to the history of the Pacific Ocean writ large, a Hau'ofian sea of islands linked to the bordering rim and the larger Asia-Pacific region. Reflecting the "Atlantic Worlds" model, the editors of Pacific Histories advocated an integrated "Pacific Worlds" approach that overcomes the fragmentation of Pacific history in favor of a more holistic study drawing on the analogy of other oceanic worlds. The collection of broad-themed essays endeavors to integrate the insular and bordering areas of the Pacific and to examine the shifts in their relations over time from the perspective of a Braudelian longue durée. The hoped-for result is the "reincorporation of the Pacific into the writing, and the rewriting, of world history today" (Armitage and Bashford 20I4, 2I).

Pacific Histories is certainly not alone in its efforts to add a more globalized perspective to Oceanian pasts. In an earlier work that anticipated Armitage and Bashford's Pacific Histories, Matt Matsuda argued in Pacific Worlds: A History of Seas, Peoples, and Cultures that the Pacific is "better described as multiple sites of trans-localism, the specific linked places where direct engagements took place and were tied to histories dependent on the ocean" $(2012,5)$. The islands of the insular Pacific-in the regions known as Melanesia, Micronesia, and Polynesia—are joined to bordering lands and peoples through extensive regional networks of voyaging, commerce, and cultural and ideational exchange. The notion of Pacific Island histories, in Matsuda's interpretive scheme, thus gives way to a focus on more global historical patterns and perspectives.

Subscribing to a Pacific Worlds approach, David Igler's The Great Ocean: Pacific Worlds from Captain Cook to the Gold Rush examines the interaction of indigenous Islanders, native communities on the North American continent, and a wide variety of foreign voyagers in the eastern Pacific (2013). Igler saw the value of a Pacific Worlds approach as residing in a "way to frame history itself: an oceanic rather than terrestrial approach, a peopled rather than vacant waterscape, a place of movement and transits, and a methodology that searches for the vital interplay between global, oceanic, and local scales of history" (20I3, II). A more 
topically focused study, Greg Cushman's Guano and the Opening of the Pacific World, follows the Pacific guano trade through time and space and links it to the histories of colonialism, science, migration, and global development (2014). The book spans the nineteenth and most of the twentieth centuries and, in so doing, joins the histories of Pacific Islands and bordering lands to metropolitan nations beyond the region. Cushman argued that the creation of agroecological systems in North America and Australasia was made possible and sustained through the mass transfer of soil nutrients from exploited islands in the Pacific. In short, the Pacific Islands were inextricably linked to the larger world and played an important role in the development of global industrial agriculture.

Getting ahead of myself a bit, I note the marked contrast between Cushman's very impressive book and Katerina Teaiwa's stunning monograph, Consuming Ocean Island (2015). I'm reminded of Dipesh Chakrabarty's characterization of the colonial archive as at once indispensable but also inadequate to the study of subjugated or subaltern people (2000). That archive, observed Chakrabarty, houses the written sources from which imperial histories are constructed. Those sources are nonetheless important for the necessary but partial colonial histories they tell; they also make possible counter-colonial histories by inadvertently underscoring the absence of and need for local histories and forms of historical expression. Teaiwa's nuanced, temporally deep, and Banaban-centered work demonstrates clearly why the colonial archive is by itself inadequate and how important are the local or indigenous histories that expand and challenge it. Hers is a creative study that foregrounds indigenous Banaban perspectives and histories in what for too long has remained a largely one-sided story of empire.

\section{The Atlantic Worlds Connection}

The Pacific Worlds perspective draws on the Atlantic Worlds approach developed and promoted by such scholars as Bernard Bailyn (2005); Alfred Crosby (2003, 2004); Philip Curtin (1998); and Jack Greene (2013). ${ }^{2}$ It involves the study "of the creation, destruction, and re-creation of communities as a result of the movement, across and around the Atlantic basin, of people, commodities, cultural practices, and values" (Elliott 2002, 239, quoted in Morgan and Greene 2009, 3). It disavows, albeit imperfectly, the primacy of "traditional national or imperial modes of organizing historical understanding" (Morgan and Greene 2009, 4). In the eyes of its 
advocates, the Atlantic Worlds model offers an "analytic construct and an explicit category of historical analysis [for the] study of one of the most important developments of the early modern era: the emergence in the fifteenth century and the subsequent growth of the Atlantic basin as a site for demographic, economic, social, cultural, and other forms of exchange" (Morgan and Greene 2009, 3), which drew together the four continents bordering the Atlantic Ocean and all the islands in between.

In a work that foreshadowed the volume Pacific Histories, David Armitage and Michael Braddick emphasized the common, the comparative, and the interactive in a study of Britain's Atlantic world (2002). They described that empire as a "vast swath of territory" that constituted neither a "singular cultural entity nor ... a systematically organized legal or governmental unit." Rather, they wrote of a transnational, multicultural reality that resulted from the "kaleidoscopic movement of peoples, goods, and ideas" (Armitage and Braddick 2002, xv, I), whose diversified patterns of production, distribution, and consumption were made possible by the international exchange that took place throughout the Atlantic basin. It was a complex, dynamic, and fluid world not easily captured by frameworks that focused on national histories.

An even broader, though very much related methodology to the Atlantic Worlds approach is World history. In the words of its proponents, World history is the search for "global patterns and processes over time and space while connecting local developments to global ones" and comparing local societal reactions to global processes (Advanced Placement World History $[\mathrm{APWH}]$ course description, quoted in Curtis and Bentley 20I4, 3). World history is about connections and the crossing of boundaries. Its primary topics of investigation have come to include "climatic change, biological diffusions, the spread of infectious and contagious diseases, mass migrations, transfers of technology, campaigns of imperial expansion, crosscultural trade, the spread of ideas and ideals, the expansion of religious faiths and cultural traditions" (Bentley 2002, 393, quoted in Curtis and Bentley 20I4, 4).

Critics of the Atlantic Worlds approach are alarmed by the imperial reach of a methodology that seems intent on "absorbing traditional fields of national and imperial study while ignoring those subjects that do not fit easily within its framework" (Morgan and Greene 2009, 5). More specifically, they raise five criticisms. ${ }^{3}$ First, the Atlantic Worlds approach lacks coherence and unity as a system, region, or civilization in the Braudelian sense. Second, the Atlantic was never a self-contained entity, as all 
seas are joined and thus not wholly separate or distinct. Third, Atlantic history is simply imperial history by a different name, "a neo-colonial, politically correct attempt at re-writing European history with some 'other bits' given deferential treatment" (O'Reilly 2004 quoted in Morgan and Greene 2009, 6). Related to this objection is the argument that the deployment of an Atlantic Worlds analytic excludes the histories of the indigenous Americas and also the histories of people of mixed heritages who were themselves the product of this transoceanic movement. The emphasis on fluidity and hybridity in effect effaces indigenous worlds and their histories in favor of the more amorphous unspecified term local.$^{4} \mathrm{~A}$ fifth and final criticism has to do with the charge that Atlantic history has focused on "transnational relations within border zones at the expense of developments within discrete areas, and even without concern about specifying how those connections and transnational relations affected the internal histories" of the metropolitan countries (Morgan and Greene 2009, 7).5

These general criticisms of the Atlantic Worlds methodology certainly resonate with some historians of the Pacific. The response to efforts to make Pacific history more transnational, global, and worldly has met with mixed enthusiasm. As a contributor to a review forum on Pacific Histories that appeared in the Journal of Pacific History, Tony Ballantyne pointed to the critically distinctive work in the Pacific that would be lost by its absorption into European and Euro-American historiographical traditions (2015). He wondered too about the value of seeking legitimacy for the histories of the Pacific Islands through reference to "genealogies of scholarship that had previously exhibited very little interest" in the islands (Ballantyne 2015, 233). The failure of the volume to deal with a diffuse body of critical interdisciplinary work leads, in Ballantyne's view, to the exclusion of serious questions concerning methodological traditions, different types of archives, and "the very nature of history itself" (2015, 234). With its focus on the European presence in the region since I 800 , the book privileges European perspectives and fails to take seriously the deeper, more expansive pasts of Oceanic islands that might have called into question Eurocentric understandings of those pasts, and the temporal and spatial sensibilities on which those understandings are based.

\section{Pacific History}

It is not surprising that Pacific history would attract the correctives of a Pacific Worlds paradigm. Pacific historians have been hard on themselves. ${ }^{6}$ 
Over the years, critics within the discipline have cited Pacific history for its insularity, its provincialism, its monograph myopia, and its failure to address larger audiences and broader themes. More pointed criticisms of Pacific history as ultimately Eurocentric reflect the field's roots in modern imperial history, an acknowledgment made by its founder. James Davidson viewed the history of empires as insufficient in grasping the diversity and complexities of colonial actors and their spheres of activity (I955). Davidson pointed to the variety of cultures, the complexity of diverse historical conditions, the relative ease in identifying local historical actors, and the comparative perspective that Pacific history offered to the study of other regions of the world. The Pacific area thus presented colonial historians with the comparative opportunity to analyze the repercussions of metropolitan policies in Island societies and against the local circumstances of those areas. European commercial penetration, the labor trade, and the impact of Christianity were among the great range of research problems that an army of Pacific historians could not hope to exhaust.

The focus of Davidson's foundational writing was on identifying the importance and necessity of bringing history to the Pacific, a history that was linked most immediately to modern European imperial history. It is a history that remains evidentiary and archival in matters of research; that focuses on contact, cultural encounters, and issues of representation; and that is concerned with the political, economic, social, artistic, and environmental consequences of colonialism. Pacific history's grace is its tacit recognition of other cultures and their histories. Pacific history's shortcoming, as Chris Ballard has noted (2OI4), remains an inability to develop a methodology for grasping and conveying those other cultures and their histories. Davidson seemed to anticipate this dilemma in his later history of Sāmoa when he wrote of indigenous cultures "as islands whose coastal regions outsiders might penetrate but whose heartlands they could never conquer" (I970, 267). It is a phrase that continues to haunt Pacific history. I read it to suggest a historiographical problem for which a Pacific history or a Pacific Worlds approach has no solution: namely, recognition of the validity and value of indigenous forms of historical expression and the complex realities they convey.

\section{The View From Mariner's Ridge}

At the risk of self-incrimination, allow me to personalize what I see as the methodological shortcomings of both a Pacific history and a Pacific 
Worlds approach. The view from our house in Hawaii Kai underscores those shortcomings. Set in the suburban community of Hawaii Kai in East Honolulu is Mariner's Ridge, on which our house sits. Our back porch overlooks Haha'ione Valley and the Ko'olau Mountains that frame the valley. From that back porch, we can see the layout of homes, the patterning of the streets, the protected watershed that begins where the encircling line of hillside homes ends, and a recreational park that is the site of weekend soccer games and large family gatherings. It's an upper-middle-class, relatively well-to-do neighborhood that is physically, emotionally, and psychologically distant from some of the more immediate problems facing the State of Hawai' $i$ and its citizens. It's a planned community, the product of American industrialist Henry J Kaiser, whose name is to be found on schools, hospitals, health plans, and various commercial businesses.

Hawaii Kai is the product of the massive development and transformation that took place in the Hawaiian Islands after statehood in 1959. ${ }^{7}$ Formal incorporation of the Islands within the United States was itself preceded by nearly two centuries of events that included contact with the Euro-American world and the companionate forces of commerce and Christianity. There followed the rise of sugar plantations, immigration from Asia, the overthrow of the Hawaiian monarchy, annexation, and the creation of a territorial or colonial government. To be sure, this is a far too brief but unfortunately true summation of settler colonialism in Hawai'i. A World or transnational history approach would be quite helpful in identifying, explaining, and contextualizing this string of developments in their more general contours. Such an analysis would certainly be important but would hardly be sufficient.

There is an oft-cited Hawaiian proverb translated into English by Mary Kawena Pukui that goes: “The top of the cliff isn't the place to look at us; come down here and learn of the big and little currents, face to face." ${ }^{8}$ At the bottom of our hill, sandwiched between the United States Post Office, the Hawaii Kai Fitness and Recreation Club, the Nanea Kai Townhouses, and the 7000 Hawaii Kai Drive Office and Condominium Complex, are the remains of the Hāwea Heiau Complex and Keawāwa Wetlands, both sites being the product of Native Hawaiian labor and initiative that preceded by centuries the construction of Hawaii Kai, when the area was a part of the ahupua'a or resource zone of Maunalua in the larger area of O'ahu known then as Kona. I am not able to recover this past in the way that Ty Kāwika Tengan and Lamakū Mikahala Roy so magnificently did for the Ahu'ena Heiau (20I4). The Ahu'ena Heiau is a paramount 
religious temple rededicated to the god Lono by Kamehameha the Great at Kamakahonu, the first capital of the Hawaiian Kingdom. It now sits on land owned by the Kamehameha Kona Beach Hotel on the Big Island of Hawai'i. Tengan and Roy recovered the history of this sacred place not seen or appreciated by most visitors, residents, or natives. Theirs is a recovery of a complicated sort that calls on oral traditions, genealogies, maps, written documents, and the testimonies of the site's kahu or spiritual guardian to tell a history that involves land, sea, family, and nation. It is a history of what was once and still endures, a history that centers indigeneity and the Hawaiian nation and people. It is the kind of history that Pacific history needs to be more mindful of - the kind of history that for many of us is more meaningful than the sweeping regional histories that inadvertently reify old, tired categories of analysis disguised in the currency, fashion, and pragmatic priorities of the contemporary historical profession. How, then, might we get closer to deeper Oceanic pasts, with their differing orderings of time and space and their culturally specific ways of doing history? To put it another way, how might we get away from that panoramic overview of Haha'ione Valley and move toward Hāwea Heiau at the bottom of the hill?

\section{History in the Pacific}

Damon Salesa has reminded us of the importance of the deeper past to more contemporary events. As an example, he explained the surprising and bold rescue of Ratu Tevita Kapaiwai Lutunauga Uluilakeba, son of the late Fijian Prime Minister Sir Ratu Kamesese Mara, off the coast of Fiji by a Royal Tongan Navy patrol boat in 20I I. Ratu Tevita had supported the 2006 military coup in Fiji but found himself charged with mutiny in 20I I. Asked to explain the Royal Tongan Navy's intervention, Siaosi Tupou V, the Tongan king, declared that he was simply coming to the aid of a kinsman. Referring to the shared histories and deep genealogical connections that link the islands of western Polynesia and bordering areas, Salesa wrote: "One cannot understand the intricacies of Sāmoan, Tongan, and Fijian contemporary politics without a firm understanding of the great lineages of these different islands such as Tui Lau, Tu'i Kanokupolu or the Sā Malietoa. These and other lineages are not merely alive in the present, but actively shape it. . . Indigenous Pacific ways, histories, languages stand not in opposition to other great forces at work in the present-postcolonialism, development, globalisation, com- 
mercialisation-but are articulate with them as well as with a deep and resonant past" (20I4, 3I).

Salesa's advocacy aside for the moment, what is known about Oceania's deeper past is for many of us not enough to escape the bonds of prehistory, a designation based on the division of indigenous pasts into the before and after periods of contact with the Euro-American world. Greg Dening suggested a way out of this impasse. ${ }^{9}$ With specific reference to the anti-historical prejudice of British functionalism, Dening wrote of the dividing moment or zero point between a Before time, when indigenous cultures were presumed to have been pure, and an After encounter time with the Euro-American world, when they were assumed to have become adulterated or corrupted. The intimate, ongoing relationship between past and present led Dening to see this distinction between history and prehistory as false. The disappearance of the zero point, he argued, involves the blurring of the division between a Before and an After, "when apparent discontinuities are transformed in the continuities of living" (2004, 5I). It is this blurring of temporal divisions and the recognition of the continuity of living with which we might approach Oceania's deeper past and thus understand any expressed consciousness of that past as history, not prehistory.

Dening's solution for transcending the limitations of colonial and still colonizing definitions of history is recognition of Deep Time. To know Deep Time requires an entrance into the ways indigenous people knew themselves and understood their world. We need to move beyond strictly empirical studies to wonder imaginatively and marvel responsibly about their settlement; about the wants, needs, and desires that motivated their founding populations; about the belief systems and daily practices that informed life on these islands and atolls; about their relationships with the larger oceanic environment; and about the contact, exchange, and tribute systems that joined them. This is an approach to the past very different from the ascendancy of progress narrative that Reinhart Koselleck critiqued so ably (2004). Koselleck reads history as a function of modernity that emerges from the eighteenth century and measures the past against a transformative, temporalized, secular story of progress and possibilities. Deep Time advances a more indigenous sense of temporality that is rooted in very different historiographical traditions.

Dening's advocacy of Deep Time seconds Epeli Hau'ofa's writings about the need for Pacific peoples to do their own histories (Hau'ofa 2008), and in ways that reflect the distinctive relationships that Pacific peoples have 
long had with their land, the surrounding sea, their gods, ancestors, and each other. Dening held "history in the Pacific" rather than "Pacific history" to be a more appropriate phrase, as it implies a tolerance for all of the varieties of history there are (1989). He thought there needed to be more history in the Pacific and less Pacific history. He opposed those who advocated "real history" - a history born of empire, empirically driven, proper in its delivery and presentation, celebratory of the nation-state, sanitized, removed or distant in time, vocational, aggressive in its political advocacy, and tied to institutions of power and privilege. Dening argued that the contemporary Pacific "needs history in the Pacific because history is liberating; . . . liberating from empires and capitalists, ... from bureaucrats and churches, from television and advertisements, and from anybody who claims our human contrivances are outside our power to change." To be liberating, he argued, "history in the Pacific needs to be vernacular and vernacularly tolerant of great variety" (Dening I989, I37). I read Dening's use of the term vernacular as a synonym for the word indigenous.

Dening would not have much patience with Jo Guldi and David Armitage's The History Manifesto (20I4), which seeks to make history relevant again through a focus on global issues, the Braudelian longue durée, and a closer relationship between historians and policy makers. ${ }^{10}$ Dening did very much believe in the persistence and creativity of nativeness. To those who argued that the search for indigenous history, historicities, and the older cosmologies and epistemologies on which they draw is too contemporary and too political, Dening would respond that history by its very nature is contemporary and political. It always represents the present in the ways it re-presents the past. The politics of history, then, is in the here and now. "Only the living have politics," he wrote, as "the dead are always waiting for resurrection [through history] to have theirs" (Dening I989, I39).

Pertinent here is Dening's 1998 evocation of John Stilgoe's notion of "looming" (1994, 24), that magical visual experience where the tricks of an oceanic horizon may turn things upside down or bring distant objects surprisingly close, clear and beyond the curve of space and time. ${ }^{11}$ Glim, as Dening reminded us, is another of Stilgoe's evocative articulations, a word for "the staggering openness in which the eye reels" from the deck of a ship or from shore to the horizon (Stilgoe 1994, 35). For a moment, there is the chance to see beyond the common, everyday limits of our vision. We might then understand Deep Time as the glim that looms on the horizon. Dening would have us use our imagination as a way to better see 
that glim. Dening's glimpsing allowed him to bear imaginative witness to the I9,000-mile flight that the yolla or muttonbirds (Puffinus tenuirostris) make around the Pacific region, an annual circuit that has been going on for centuries $\left(2004, \mathrm{I}_{4}-\mathrm{I} 5\right)$. They had fed first settlers, and their numbers later amazed European voyagers who saw them in the southwestern and northeastern extremes of Oceania. The yolla, then, link a deep past to present times. Dening saw in the yolla's annual circumnavigation of Oceania an affirmation of the region's vastness, its diversity, its resilience over time, and its persisting vitality.

Dening also saw looming on that horizon the Vava' $u$, the doublehulled voyaging canoe or va'a tauna that left Tonga, or perhaps Sāmoa, to travel thousands of miles across open ocean to reach what he termed Fenua'enata, a group of islands known today as the Marquesas (2004, 7). Dening described the materials used to build the majestic canoe, its construction, its design, the names of its many constituent parts including the wood hulls called Taipi and Teii, and the long history of voyaging that preceded and made possible its launch. He located the voyage as having taken place during Mei, the time of abundance, fruiting, and harvesting, when the stars Mataiki, $\mathrm{Na} \mathrm{Kao,} \mathrm{and} \mathrm{'Ana-Muri} \mathrm{were} \mathrm{rising} \mathrm{and} \mathrm{Metau-o}$ Maui and Mataiki were setting. ${ }^{12}$ He visualized its cargo of nuts, seeds, cuttings, obsidian, pottery, and the capital of cultural knowledge contained in the heads of those adults who made the voyage. Dening wrote of the skills of its navigators, the length of the voyage, and its most likely route, first to the north around the Tuamotus, past the Tahitian islands, and then to the south. He guessed their initial landing to have been at $\mathrm{Ua}$ Huka, with some sailing on to settle the more hospitable and welcoming island of Nukuhiva.

Much of this glimmering is riddled with Dening's uncertainties; he was not sure of the beach from which Vava' $u$ was launched, its actual course, or the names and numbers of the great canoe's occupants. But his is not fiction. Rather, Dening wrote as a magical realist whose reflections drew from a multiplicity of sources and media. Through his glimpsing of Deep Time on the horizon, Dening subverted conventional academic tropes. He asserted that "research ... requires courage; that imagination need not be fantasy; that freedoms do exist in non-fiction; that creativity can be collegial and communal; and that true stories are entrancing" (Dening quoted in Griffiths 2009, 74.8). That's what the stories of the Vava'u and the yolla do; they encourage us to escape a Eurocentric Pacificism that distorts and distracts rather than imagines what is possible to know. 


\section{Critical Ethnographies}

As previously noted, to know Deep Time requires an entrance into how earlier peoples knew themselves, understood their worlds, and expressed their histories in ways that were culturally particular and distinctive. This raises the issue of indigenous historicities. Chris Ballard described indigenous historicities "as the modes of temporal being and awareness specific to particular communities at particular moments in time; they inform the production of the historical past, as historical agents operate within the terms of their own historicities, but they also frame our conscious and unconscious awareness of temporal process" (2014, I03). How then do we begin to approach these indigenous historicities and the worldviews and lifeways that inform them? We might first turn to critical ethnographic practices, especially those that link past to present and are as much about continuity through change as they are about disruption and dislocation. The book Like People You See in a Dream (Schieffelin and Crittendon I99I) sought to glimpse something of the cosmological backgrounds that informed the response of different Papuan Plateau and Southern Highlands people to the 1935 Strickland-Purari colonial patrol commissioned out of Port Moresby. These separate and distinct encounters are analyzed through the histories that preceded them, the distinctive ways in which those histories are remembered and transmitted, the shock of otherness, and the challenge to the extant social and political structures of the time.

Roger Keesing's Kwaio Religion documents a Solomon Islands people who, into the I980s, resisted capitulation to the West (I982). Keesing described Kwaio religion in a way that captures "the phenomenological reality of a world where one's group includes the living and the dead, where conversations with the spirits, and the signs of their presence and acts, are a part of everyday life" (1982, 260). "For a century, Kwaio [had] known the power of the Europeans, had heard the Christian message," and even ventured abroad on sailing ships to work as laborers in the cane fields of Fiji and Queensland. "Their conservatism," wrote Keesing, was "born of struggle not isolation" (Keesing 1982, 2). The Kwaio found themselves surrounded "not only by a government committed to Westernstyle development ... and evangelists whose weapons of conversion ... include[d] antibiotics and airplanes, but [also] by their own militantly Christian kin along the coast, [who sought] to gain control over mountain lands and reluctant souls" (Keesing I982, I). "Kwaio religion as a system of meanings ... [used] the experiences of dreams, coma, and memory, 
the physical signs of shadow and reflection, transmutations of smoke and steam, and the processes of birth and death to create the implicit terms and categories of a metaphysic and eschatology" that informed their history making (Keesing I982, 24I-242).

Stuart Kirsch recommended that we employ a reverse anthropology that foregrounds indigenous modes of analysis (2006). He focused on the efforts of the Yonggom people to seek legal redress against the environmental degradation caused by the Ok Tedi copper and gold mine in western Papua New Guinea, and on the experiences of 6,000 Yonggom or Muyu refugees from the Indonesian territory of West Papua into Papua New Guinea in 1984. Yonggom histories "interpret their historical encounters with Euro-Americans in terms of social relations and exchange rather than ... separation and difference based on either culture or race." Not all history is "narrative in form; [some] history is inscribed in place through ... interactions with the landscape." Histories are also inscribed in "conceptions of generational time, most notably in relation to the lives of the aman dana, the children of the future" and the concern for cultural loss (Kirsch 2006, 21 8). Kirsch argued for the recognition of indigenous modes of analysis, especially the interpretive capacities of Yonggom myth, ritual, magic, and exchange that are all a part of their history and history making.

Recognition of indigenous modes of historical analysis and interpretation figures prominently in Jack Taylor's The Other Side: Ways of Being and Place in Vanuatu (2008). Taylor found in the textile patterns and architectural designs of the Sia Raga people of North Pentecost Island a pattern or motif as profoundly epistemological as it is functional or decorative. For the Sia Raga, the design of the tree, with its ribs or branches spreading out equally on either side from a central or supporting spine, is a cosmological pattern that connects and explains understandings of genealogy and history. Of special note is the primacy given to Sia Raga histories. Taylor narrated the history of Jimmy, a nineteenth-century white man who adjusted well to life in North Pentecost and whose story provides a framing for the history of that particular time in the Sia Raga past. Taylor's concern is not to validate the Sia Raga history of Jimmy against Western sources but to give prominence to past events, partial ethnographic understandings, and the blurring of the individual self that emerge from this local historical practice. ${ }^{13}$

Similarly, Richard Parmentier saw the Palauan past as revealed through physical signs that serve as historical markers of events deemed signifi- 
cant, memorable, and thus historical (1987). The texts or sources of the Palauan past include stones, hillsides, other geographical features, and the physical layout of Palauan villages where spatial configurations and distinctive architectural features offer a diagram for Palau's deep political history. In like manner, Chris Ballard wrote of the complex and overlapping density of peoples, place-names, and historical events among the Huli of the Southern Highlands of Papua New Guinea. In terms of Huli historicity, an event that happened in I 860 is just like yesterday. "Huli genealogies," wrote Ballard, "form a matching temporal grid, extending vertically to more than fifteen generations and laterally to encompass men, women, and the connections made through them, as well as siblings in their correct birth order and those who died in infancy" (2014, I06).

As indicated earlier, there is certainly variation in the ways that engagements with capitalism are narrated and understood. Katerina Teaiwa reminded us of how, on Rabi, Banabans' resistance to their exploitation and displacement is choreographed and the island's history "reinforced and reenacted on every occasion they perform in the now iconic historical dance theater in Fiji and beyond" (2015, I77). In contrast, Ira Bashkow wrote of how the Orokaiva people of eastern New Guinea measure their relationship to modernity against the whiteness of the people who brought it and the local history that preceded that bringing (2006). The volume Emplaced Myths (200I), edited by Alan Rumsey and James Weiner, takes a comparative focus on indigenous worlds in Australia and New Guinea that are being affected by major development projects such as mining, drilling, and foresting. The various contributors wrote of lifeways that are in conversation with global circuits of power. These "lifeways ... are not mere relics of a premodern past"; rather, "they are rooted in earthly places no less tangible" and historical than the culturally inscribed resources cut, drained, or otherwise extracted from them (Rumsey 200I, I6).

\section{A More Radical Indigenous Historiography}

The contributions of such critical ethnographies are helpful in underscoring the power and persistence of different cosmologies, epistemologies, and historicities. I turn now to a more radical and indigenous reading of the deeper past and the possibilities it offers for a more liberating historiography. Vince Diaz has advocated indigenous, polysemic discursive play or flourish as an analytical approach that disrupts conceptual tyranny of all sorts, including that which can result from the practice of his- 
tory (2010, 2016). For Diaz, the canoe is an analytical or heuristic device that allows, among other things, for alternative readings that subvert or undermine Pacificisms or colonialist readings of the past that continue to distort and oppress in contemporary times. He interrogated the assassination of the Spanish Jesuit missionary Diego Luis de San Vitores by the Chamorro chief Si Maga'låhi Matå'pang that took place in I672. Citing the work of Chamorro medical anthropologist Vince Diego, Diaz focused on Chamorro concepts of emmok (revenge), manhihita (solidarity), and matakña, an aggressive, public, chiefly response to personal affronts.

San Vitores's defiance of Matå'pang, manifest in his insistence on proceeding with the baptism of the chief's child despite an order to the contrary, comes in front of villagers, including children. Matå'pang's response to this profound public insult is one of culturally predictable violence or matakña. This reading repositions both missionary and priest such that Matå'pang's killing of San Vitores becomes culturally contextualized against the rising opposition to Spanish domination that resulted in the Spanish-Chamorro wars of the late seventeenth century. According to Diaz (2016, I26), this interpretation challenges the official church view that "subordinates rebel politics and their cultural prescriptions beneath a theological one" and that regards Matå'pang as an enemy of the Roman Catholic faith. What results from Diaz's indigenous discursive flourish is a role reversal, akin to contemporary Chamorro nationalist sentiment, in which the Chamorro chief becomes the hero and the priest is the transgressor. But there is more. Diaz examined Francisco Garcia's seventeenth-century hagiography of San Vitores with special attention to the role of Matå'pang's canoe in the disposal of the priest's body in Tomhom Bay. His close reading of Garcia's account suggests that the priest may not have been dead and, in fact, sought to save himself from a watery grave by grasping the outrigger of the canoe. Diaz asked, "What does it do to the posthumous canonical narrative of martyrdom if San Vitores was still alive at this time and was actually fighting for his life?" (2016, I29-I30).

Diaz was not through, however, with this indigenous flourish. He used the Tagalog cognate of Matå'pang's name, mátapang-without the glottal stop and with a stress on the first syllable-as cargo for a metaphoric outrigger canoe that links to the larger Austronesian world, with its traditions of voyaging and migration stretching from Indonesia in the west to Madagascar in the east. Like Nick Evans (20I0), Diaz traveled the logosphere, the floating world of ancestral words, to find historical linkages that con- 
nect ancient worlds in ways that can be surprising and unexpected. Here is a longue durée that encompasses a huge part of the globe.

Diaz argued that the historical person Matå'pang and the lexical term mátapang are cognates to an interesting set of other names and words among a host of Austronesian languages that cover at least three different cultural attributes and their polar opposites, including denotations of hyper-absence and presence, saturation and emptiness. The ubiquity of the canoe, coupled with an indigenous discursive flourish, allow Diaz to develop a transnational form of critical indigenous studies that, in his words, "can help keep pace with the enduring, complex, contradictory, and indefatigable habits of Indigenous peoples" (2016, I20). This indigenous discursive flourish embraces the concept of indigeneity as a floating stabilizer whose function, like the outrigger itself, is to keep the canoe of native histories and subjectivities balanced and on course amid the stormy seas of colonial and postcolonial forces. ${ }^{14}$

Diaz's indigenous discursive flourish extends to the very notion of islands. He sees them as not only mobile or moving-a point he's made in several of his publications (I995, 20I0, 20I I; Diaz and Kauanui 200I)— but also capable of both contraction and expansion as their limits are determined by the range of the indigenous creatures who occupy their land, sky, and sea space. He stresses the fluidity and connectivity of islands across vast expanses of sea and space and the profound temporal depths of these features. He uses the canoe and, more generally, seafaring cartographies and practices to advance more radical and archipelagic epistemologies and to critique commonplace conceptualizations about traditional seafaring, the gendered and sexualized dimensions of that seafaring, and about islands and greater Oceania. He argues that reigning understandings of "Islands" and "Islanders" are products of continental and imperialist thinking and that to continue to treat these as natural, unproblematic categories of existence and being is to obfuscate the histories by which imperialism and colonialism continue to define the Pacific (Diaz 2015 b, IOI-IO2).

Raised on Guam and of Filipino and Pohnpeian ancestry, Diaz thus provides a way to engage defiantly with the forces of globalization. His indigenous discursive flourish also invites us to think differently about deeper Oceanic pasts that are locally ordered and globally connected, but on terms and in ways that are distinct from both Pacific history and the more global and transnational paradigms that are more current today. His work points to an indigenous Deep Time in which there was not only 
a consciousness of other places but also engagements with those other places and their peoples-an indigenous World history, if you will. Like Dening, Diaz offers, in a different but complementary way, an escape from the historiographical triad of contact, encounter, and colonialism that has been the focus of much Pacific history.

\section{PoHnPei}

Transnational histories allow for little to no consideration of the details and particulars that are so crucial to Island histories and Island history making. These histories form part of the roots that make possible embarkation on other traveling routes. For those who prefer their histories more materially grounded, there is Rufino Mauricio's 1993 doctoral dissertation, "Ideological Bases for Power and Leadership on Pohnpei, Micronesia: Perspectives from Archaeology and Oral History." It is a strong, persuasive indigenous history that should have been published. Using archaeology and oral traditions, Mauricio investigated the foundational history of two regional, religiously based polities in the west and south of the island of Pohnpei-Salapwuk and Onohnleng, respectively-that eventually joined to help form the current chiefdom of Kitti, one of five on the island today. ${ }^{15}$

Equally adept at deep historical ethnography, Mauricio examined the Pohnpeian cosmos. He noted that Pohnpeian cosmology not only included the association of the sky world with local deities but also marked the movement of celestial bodies and the correlation of those movements with the seasons. These observations allowed Pohnpeians to divide their lunar year into two general seasons consisting of ten named periods of time that corresponded roughly to the months of the Gregorian calendar. The priestly leaders of Salapwuk and Onohnleng scheduled their rituals and ceremonies to align with these celestial movements and correlated earthly events. Emphasizing the linkage of the supernatural, human, and natural worlds, Mauricio understood Pohnpeian temporality in this foundational period as markedly different from Euro-American forms of time that measure the past against a transformative, linear, and secular story of progress and possibilities. In the case of Pohnpei, the traditional religious beliefs and practices became political instruments that sanctified power and authority and were instrumental in the emergence of more secular regional polities.

In support of his work, Mauricio provided an impressive list of sites, associated activities, and the titles of priests and local leaders involved in 
the maintenance of the two religious sites. In addition to an archaeology that is sensitive to history, Mauricio relied heavily on historians of the island who provide varied narrations of the past as historical happenings in need of remembering. Mauricio paid attention to the varied kinds of historical knowledge presented, the contexts in which this knowledge is imparted, and the clan affiliations, family lineage, religious allegiances, and personal rivalries that informed the historians' accounts. He wrote of a vibrant, varied, and contested world that defies an easy summation or a neat location in time.

Mauricio also wrote of the perils of archaeological and historical research into sacred knowledge and spiritually saturated spaces. His research into the history of the Salapwuk area had been done with the permission and under the supervision, training, and instruction of Oaulik Leng, the senior oral historian and ritual leader of Salapwuk. The affinity between Oaulik Leng and Mauricio stemmed from their membership in the same clan, the Dipwenpehpe. Mauricio's clearing and mapping of a particularly sacred site-the burial place (called Elen Eni) of those who had held the chiefly ruling title of Saum en Leng over the centuries-brought heavy rains that were interpreted as supernatural displeasure by other residents of Salapwuk. The next day, an often-sickly Oaulik died. Mauricio lamented, "I was saddened, shocked, and perplexed by this crisis. Whether Oaulik's dead $[s i c]$ and my role in disturbing the site represent an unfortunate coincidence or some cause and effect phenomenon is beyond my ability to explain. To the people of Salapwuk, some of whom are convinced that my work at the site precipitated the crisis, the incident reinforces their believe [sic] in the sanctity of their land and the interconnectedness between their past and their present experiences" (I993, 257-258).

History in Oceania needs to be inclusive of the sensual, the performative, the exhibitive, oral traditions, different historicities, and varied but informing cosmologies and epistemologies. There also needs to be a recognition of the incommensurable in the rooted histories of Pacific or Oceanic islands. ${ }^{16}$ As Mauricio noted in a related work, there is a strong and persisting belief on Pohnpei that the land has its own life and its own authority: "People are born and die on the land but the land remains a sanctuary of ancestral beliefs and traditions" (Mauricio [2015], 5). One of the several appendices to Mauricio's dissertation provides the names and descriptions of fifty Pohnpeian deities and spirits. Among them are Nahnsahuen Sed and Limwohdeleng. Nahnsahuen Sed is considered an eniwehs, a transcendent spirit who dwells in the mangrove forests that 
surround parts of the island. He is described as an ugly, unkind being who creates fear and causes illness in people-illness that only he can cure after being properly propitiated. Limwohdeleng is an ancestral spirit of the Dipwilap clan who appears either as a beautiful seductress whose charms cause men to become insane or as an elderly woman who offers cooked breadfruit from her carrying basket to those whom she encounters. Eating the proffered breadfruit has the similar effect of bringing on insanity in the unsuspecting consumer. I mention Nahnsahuen Sed and Limwohdeleng because they are the only two spirits I encountered during my times on the island.

I have no rational, analytic, or scientific explanation for understanding those encounters, and I resist the temptation to theorize them. In truth, I was then and remain today somewhat ambivalent and uncertain about my encounters with Nahnsahuen Sed and Limwohdeleng, though the people I was with at the time did not share that ambivalence and uncertainty. I have no doubts, however, about witnessing a sorcerous practice designed to bring harm to its victims. Kau is often translated from the Pohnpeian as harmful magic or sorcery (Rehg and Sohl I979 24). There are various kinds of kau employed against one's rival or enemy. One kind of kau is referred to as wie me sarawi kapir or "flying magic" (Mauricio, pers comm, 27 Dec 20I5). It involves burning a pile of dried coconut palm leaves or coconut stems, uttering the appropriate incantations or prayers, and then cutting the flame with a knife in such way that the flame is sent flying to the dwelling of one's enemy or rival. Kau is carried out late at night to minimize detection. Unless the kau is countered, the victim will sicken and die (Riesenberg I948, 4I0).

My wife Kathy and I were stone sober in a boat traveling along the western coast of Pohnpei on our way from Wone to the central town of Kolonia in the north where we would catch a plane home back to the United States after three years of work at the Community College of Micronesia. This was in 1980. The head of the family to which we belonged, Benno Serilo, known more appropriately by his title as Souroko en Tiren Sapw Kitti, was driving. The tides had forced us to travel at night and outside of the reef, but not out of sight of land. As we paralleled the central Kitti coast, I saw a ball of flame ascend from the area around Poahleng and fly south toward Rohnkiti, where it began to drop. I knew what I had seen, but being startled by the sight, I turned to Souroko sitting in the back of the boat by the engine and asked what it was. He waved my question off and looked away. 
Histories that come to us from the deep past won't always tell us what we want or expect to hear. In what I think is one of the most underappreciated texts on Oceanic history, Klaus Neumann reminded us of the plurality of voices, the politics of knowledge, the contested and partial nature of accounts, and the personal and cultural contexts that inform local narrations of the Tolai past (I992). Any effort to bring these histories to a larger non-Tolai audience necessitates a delicate, complex exercise in translation and mediation. Histories from the deep past may also require us to confront the unsettling, the inexplicable, and the incommensurable. Nonetheless, I cite the encounters with the powers of the land not to sensationalize, titillate, or add yet another layer to an ethnographic or historical Pacificism. Instead, I narrate them in support of a deep time that is still with us and a form of history that can at least acknowledge the possibility of other realms and dimensions of being.

\section{The Continuities of Past and Present}

Having placed myself in what many will regard as a professionally untenable position, let me enlist the support of a Pohnpeian sorcerer to escape. I refer to Wehsekleng, who at the end of his life held the title of Nahnapas en Kitti. Among the people of southern and southeastern Pohnpei, Wehsekleng, in the first decades of the twentieth century, was a revered priest, deeply knowledgeable historian, and a feared sorcerer (Hanlon I999, $72-72, n 78$; Mauricio I993, 372). He played an instrumental role in the I 852 war between the chiefdoms of Kitti and Madolenihmw and later predicted the 1905 typhoon that devastated the island, leveling every large tree and creating a severe food shortage that lasted for a considerable time after the typhoon. How he was able to predict that typhoon I do not know, but he was certainly not alone in being able to read and forecast the natural world around him, then and now. Doaropwehda is the Pohnpeian word that means "to predict with the help of magic" (Rehg and Sohl I979, 209). Like other sorcerers on Pohnpei and elsewhere in Oceania, Wehsekleng could often predict the weather with supernatural assistance and through special attentiveness to changes affecting the wind, seas, sky, and physical environment. Employing a modest amount of metaphoric license, I contend that divination of a sort is not a skill that has been lost in contemporary times, as evidenced by Oceanic peoples' readings of their island world and the human-made forces that threaten its future.

The renewed emphasis on environmental conservation and preservation 
in Palau reflects long-standing patterns that come forward from the distant past (Johannes I98I). In the Marshalls, bwebwenato or stories underscore the people's historical relationship with the land and surrounding sea, a relationship that endures despite the devastating effects of United States nuclear testing (Tobin 2002). And what are the current global tour of the canoe Hōkule $a$, the recovery of traditional navigation in the Marshall Islands as embodied in the canoe Jitdam Kapeel (Genz 2008), and the gathering of Micronesian canoes for the 20I6 Pacific Festival of the Arts on Guam, if not celebrations of Oceanic voyaging and exploration and the indigenous knowledge and histories of travel that preceded them?

We should not be surprised, then, by the fact that those most deeply affected by global warming and climate change are near the forefront of international efforts to arrest pollution and other forms of environmental degradation. Awareness of their past, present, and future compel them to do so. Witness the Majuro Declaration, the Micronesian Challenge, the 2015 Boknake Haus Communique of the I5th Micronesian President's Summit, the 2015 Taputapuatea Polynesian Leaders' Declaration on Climate Change, the Suva Declaration on Climate Change from the Pacific Islands Development Forum, and the efforts of the Melanesian Spearhead Group on Environment and Climate Change. Consider too that the Republic of Fiji, the Republic of Palau, and the Republic of the Marshall Islands were the first three nations to ratify the United Nations Climate Change Agreement (Climate Nexus 20I6). These are actions in the present informed by a deeper past. As Margaret Jolly has argued (2015), we ignore indigenous knowledge and histories at our collective peril.

Teresia Teaiwa cautioned against stopping our investigations into Pacific studies because the global marketplace of knowledge does not value the region or values it only in certain ways (2006). I would add that we should not reorder our study of Oceanic pasts to accommodate historiographical trends that emphasize the pragmatic, practical, and utilitarian as defined from elsewhere. That said, I believe Pacific history needs very much to be in conversation with other histories and other historians. Regional, transnational, comparative, and global approaches all have their value. But I would urge Pacific and World historians to be more tolerant, appreciative, and accommodating of the indigenous histories of Oceania that engage with the deeper past; that are bold, imaginative, and liberating in their approach; that look beyond the conventional lenses of contact, encounter, and colonization; and that embrace varied and distinctive ways of narrating, understanding, and conceptualizing the past. 
I give the last words to James Clifford (2013), who is genealogically linked to several of the writers I have considered in this essay. He has helped some of us to identify the resurgence of indigeneity that is at once global and local and that is informed by histories and historical practices that come from the deeper past. With the supremacy of the West now in question in the early twenty-first century, indigenous people have emerged through generations of survival, struggle, and renewal. They have responded to modernity in a variety of ways ranging from adaptation and appropriation to resistance. Indigenous people have become increasingly visible as they move through local, regional, and global networks. To understand these movements, Clifford has called for an ethnographic and historical realism that eschews both Western triumphalism and savage romanticism. He, like many of us, retains a strong belief in the persistence, durability, and creativity of nativeness.

Clifford has tracked "the processes of colonization, globalization and indigenous becoming" as they "construct, reinforce, and trouble each other" $\left(2 \mathrm{II}_{3}, 8\right)$. The tone of his work remains optimistic and full of possibilities for indigenous people who now live in a "world system that can no longer be spatialized into stable cores and peripheries, that is susceptible to deep crises and profound reconfigurations" (20I3, 2I I). In place of earlier metanarratives, he sees history as contingent and open-ended. And he takes seriously the "indigenous longue durée," which is "the idea that disruptions caused by colonization, settler-colonialism and modernity can be better seen and understood as brief moments in much longer histories that are passing on the way to more hopeful futures" $(2013,42)$. This strikes me as a very persuasive manifesto for the current and future practice of history in Oceania.

I PRESENTED THIS PAPER as the closing keynote address for the 2016 Pacific History Association (PHA) conference, "Mo'na: Our Pasts Before Us," held on Guam from I9 May through 2 I May 20I6. I thank the organizers of that conference, Drs Anne Perez Hattori and James Perez Viernes, for the opportunity to address the PHA membership. I have attempted to retain many of the features of my oral presentation while also honoring the editorial conventions and style guidelines of The Contemporary Pacific. I wish to acknowledge journal editor Alex Mawyer and managing editor Jan Rensel for their support and assistance, as well as the external readers who reviewed an earlier draft of this article. Special thanks are due Vince Diaz for his critically constructive and encouraging comments on 
my interpretation of his work and also Richard Rath for his help in guiding me through the considerable body of literature on the Atlantic Worlds approach to history. I am indebted as well to Geoff White for his recommendations of recent Melanesian ethnographies dealing with history and historicity.

\section{Notes}

I Margaret Jolly addressed the limitations of the term Oceania for some island people, especially those living in the interior areas of Papua New Guinea and other Melanesian islands (200I).

2 Armitage and Bashford conceded that the employment of an Atlantic Worlds approach on Pacific pasts is bound to be inexact and misleading (20I4, 9). Still, the parallels and similarities are striking.

3 For an extended summary of the Atlantic Worlds approach as well as criticisms of it, see Greene and Morgan 2009. The editors of that volume ultimately argue for its utility and helpfulness: "By raising historical discussions of the Atlantic world to a level that transcends both nations and empires, it has contributed to the development of analytical procedures for describing experiences and connections that were multiracial, multiethnic, multinational, and multi-imperial” (Morgan and Greene 2009, 24).

4 On the ways in which the "local" can be used to elide or evade the indigenous, see Byrd 20II, Warrior 20I5, and Weaver 20I4.

5 For more ethnographic-based histories critical of the Atlantic Worlds approach, see Barr 2007; Coffman, Leonard, and O'Reilly 20I5; DuVal 2007; Hall 2009; Kupperman 2000; Sweet 20II; and Warsh and Morgan 20I4. As critical as these works are, many employ formulaic deconstructions of first encounters between Europeans and Native Americans. They rely heavily on counter readings of the colonial archive that include writings by explorers, travelers, missionaries, and government officials, complemented by anthropological and archaeological studies. Deeper Native American pasts remain largely beyond these advocate histories.

6 For critical assessments of Pacific history since its inception as a formal field of inquiry in I954, see Howe I979, I992; Hanlon 2003; Munro and Lal 2006; and Daws 2006. For a more recent survey of the discipline's development, there is Douglas 20I 5 .

7 There is very little written about the history of Hawaii Kai outside of archaeological surveys, environmental impact studies, design plans, and government reports, all linked to the physical development of the area since the I950s. Popular accounts of the area's history include Stump I98 I and Hancock I983. An online website that endeavors to present a broader history of the area that includes the deeper Hawaiian past is Maunalua.net (2015). 
8 This saying is quoted in T Teaiwa (200I, 343) and Lyons and Tengan (201 5 , 546). The source for both is Pukui $(1986,24)$. See also Teaiwa's essay "Mānoa Rain” (2004) for its sense of groundedness in approaching the Hawaiian past.

9 This portion of my essay draws from an earlier presentation (Hanlon 20I4). A revised version of that presentation is in a volume edited by Warwick Anderson, Miriam Johnson, and Barbara Brooks and currently under review by the University of Hawai'i Press.

Io For an extensive summary of the debate around Guldi and Armitage's The History Manifesto (2014), see Zukas 2015.

I I Tom Griffiths offered a very poetic and incisive account of the critical role that creativity and imagination play in Dening's scholarship (2009). With respect to Dening's use of Stilgoe's notion of looming, Diaz has cautioned that the horizon is not set but rather a function of one's specific location (20 I 5 a). This more fluid understanding of the horizon frames the relationship between the "out there" or global and the local in more indigenous terms that allow for a greater temporal depth and spatial range.

I 2 These are Dening's spellings for the names of stars in the Polynesian sky. They are rendered differently in the various languages of the region. The Pleiades, for example, is Makali'i in Hawaiian, Matari'i in Tahitian and Tongan, and Matariki in Māori.

I3 In this section, I draw on my description of Taylor's work in the editor's note introducing that volume (Taylor 2008, vii-viii).

I4 Diaz addressed a global community of indigenous peoples linked by struggles to maintain their native histories and subjectivities amid the stormy seas of colonial and postcolonial forces. He thus underscored "the routedness of indigenous travel through the 'rootedness' of indigenous knowledge" (Diaz 2OI 5, 608nI3). Ty Tengan reminded us that claims to being autochthonous still very much matter. He noted too that the indigenous is "as inherently situational, hybrid, syncretic and articulated as it is grounded in genealogy and land. This very diversity of experience and positionality is a strength when it is understood as broadening and enlarging the space of indigeneity, rather than completely erasing it" $(2005,253)$.

I 5 In his dissertation, Mauricio addressed the relationship linking archaeology, history, and oral traditions (1993, 5-9, 20-24). See also Hanlon 1990. In arguing against the distinction between history and prehistory, Patrick Kirch admitted to archaeology being a form of history (2000). Paul Rainbird's history of archaeology in Micronesia also offers a thematically and theoretically sophisticated approach to the region's deeper past (2004).

I6 I endeavored to address the issue of incommensurability in history in an earlier piece; see Hanlon I992. Drawing on the work of Tambiah I990, Thomas I97I, and Thompson I978 as well as my own research and personal experience on the island of Pohnpei, I argued for a more indigenous, sensitive, and different 
way of doing history in the Pacific that allows for the reality of other dimensions of being.

\section{References}

Armitage, David, and Alison Bashford, editors

2014 Pacific Histories: Ocean, Land, People. New York: Palgrave Macmillan.

Armitage, David, and Michael J Braddick, editors

2002 The British Atlantic World, I500-I800. New York: Palgrave Macmillan.

Bailyn, Bernard

2005 Atlantic History: Concept and Contours. Cambridge, mA: Harvard University Press.

Ballantyne, Tony

2015 Perspectival Histories. In Review Forum: Pacific Histories: Ocean, Land, People, edited by David Armitage and Alison Bashford. Journal of Pacific History 50 (2): 232-235.

Ballard, Chris

20I4 Oceanic Historicities. The Contemporary Pacific 26:96-I 24.

Barr, Juliana

2007 Peace Came in the Form of a Woman: Indians and Spaniards in the

Texas Borderlands. Chapel Hill: University of North Carolina Press.

Bashkow, Ira

2006 The Meaning of Whitemen: Race and Modernity in the Orokaiva

Cultural World. Chicago: University of Chicago Press.

Bentley, Jerry

2002 The New World History. In A Companion to Western Historical Thought, edited by Lloyd Kramer and Sara Maza, 393-4 I6. Oxford: Blackwell.

Byrd, Jodie A

201 The Transit of Empire: Indigenous Critiques of Colonialism. Minneapolis: University of Minnesota Press.

Chakrabarty, Dipesh

2000 Provincializing Europe: Postcolonial Thought and Historical Differ-

Clifford, James ence. Princeton: Princeton University Press.

2013 Returns: Becoming Indigenous in the Twenty-First Century. Cambridge, MA: Harvard University Press.

Climate Nexus

2016 With Europe on Board, Paris Climate Agreement Takes Effect. Online 
at climate.nexus.org.about-us/paris-agreement/factsheet-entry-force -process-paris-agreement [accessed 27 Dec 20I6]

Coffman, D’Maris, Adrian Leonard, and William O'Reilly, editors 2OI 5 The Atlantic World. London: Routledge.

Crosby, Alfred W

2003 The Columbian Exchange: Biological and Cultural Consequences of I492. 3 oth anniversary edition. Westport, Ст: Praeger.

2004 Ecological Imperialism: The Biological Expansion of Europe, 900I900. 2nd edition. New York: Cambridge University Press.

Curtin, Philip D

I998 The Rise and Fall of the Plantation Complex: Essays in Atlantic History. 2nd edition. Cambridge, uk: Cambridge University Press.

Curtis, Kenneth R, and Jerry H Bentley, editors

20I4 Architects of World History: Researching the Global Past. Malden, mA: Wiley-Blackwell.

Cushman, Gregory T

20I4 Guano and the Opening of the Pacific World: A Global Ecological History. New York: Cambridge University Press.

Davidson, James W

I955 The Study of Pacific History: An Inaugural Lecture Delivered at Canberra on 25 November 1954. Canberra: The Australian National University, Research School of Pacific Studies.

I970 Lauaki Namulau'ulu Mamoe: A Traditionalist in Samoan Politics. In Pacific Islands Portraits, edited by James W Davidson and Deryck Scarr, 267-299. Canberra: The Australian National University Press.

Daws, Gavan

2006 Texts and Contexts: A First-Person Note. Journal of Pacific History 4I (2): 249-260.

Dening, Greg

I989 History "in" the Pacific. The Contemporary Pacific I:I34-I39.

I998 Readings/Writings. Melbourne: Melbourne University Press.

2004 Beach Crossings: Voyaging Across Times, Cultures, and Self. Philadelphia: University of Pennsylvania Press.

Diaz, Vicente M

I995 Moving Islands: Toward an Indigenous Tectonics of Island Historiography. Paper presented at Center for Pacific Islands Studies conference Contested Ground: Knowledge and Power in Pacific Islands Studies, University of Hawai'i at Mānoa, December.

2010 Repositioning the Missionary: Rewriting the Histories of Colonialism, Native Catholicism, and Indigeneity in Guam. Pacific Islands Monograph Series 24. Honolulu: Center for Pacific Islands Studies and University of Hawai'i Press. 
20II Voyaging for Anti-Colonial Recovery: Austronesian Seafaring, Archipelagic Rethinking, and the Re-mapping of Indigeneity. Pacific Asia Inquiry 2 (I): 2 I-32.

20I 5a Native Pacific Studies and the Illinois Debacle: Indigeneity at the Edge of Nationalist Belongings and the Limits of Signification. In Pacific Currents, edited by Paul Lyons and Ty P Kāwika Tengan. Special issue of American Quarterly 67 (3): 597-608.

20I 5 b No Island Is an Island. In Native Studies Keywords, edited by Stephanie Nohelani Teves, Andrea Smith, and Michelle Rajeha, 90-Io8. Tucson: University of Arizona Press.

20I6 In the Wake of Matå'pang's Canoe: The Cultural and Political Possibilities of Indigenous Discursive Flourish. In Critical Indigenous Studies: Engagements in First World Locations, edited by Aileen Moreton-Robinson, I I9-I37. Tucson: University of Arizona Press.

Diaz, Vicente M, and J Kēhaulani Kauanui, editors

200I Introduction. Native Pacific Cultural Studies on the Edge. Special Issue of The Contemporary Pacific I 3:3 I 5-342.

Douglas, Bronwen

2015 Pasts, Presents and Possibilities of Pacific History and Pacific Studies: As Seen by a Historian from Canberra. Journal of Pacific History 50 (2): 224-228.

DuVal, Kathleen

2007 The Native Ground: Indians and Colonists in the Heart of the Continent. Philadelphia: University of Pennsylvania Press.

Elliott, John

2002 Afterword. Atlantic History: A Circumnavigation. In The British Atlantic World, I500-I800, edited by David Armitage and Michael J Braddick, 233-249. New York: Palgrave Macmillan.

Evans, Nicholas

2010 Dying Words: Endangered Languages and What They Have to Tell

Genz, Joseph H Us. Chichester, uk: Wiley-Blackwell.

2008 Marshallese Navigation and Voyaging: Re-learning and Reviving Indigenous Knowledge of the Ocean. PhD dissertation, University of Hawai'i at Mānoa.

Greene, Jack P

2013 Creating the British Atlantic: Essays in Transplantation, Adaptation, and Continuity. Charlottesville: University of Virginia Press.

Greene, Jack P, and Philip D Morgan, editors

2009 Atlantic History: A Critical Appraisal. New York: Oxford University Press. 
Griffiths, Tom

2009 History and the Creative Imagination. History Australia 6 (3): 74. I74.I 6.

Guldi, Jo, and David Armitage

2OI4 The History Manifesto. Cambridge, uk: Cambridge University Press. Hall, Joseph M, Jr

2009 Zamumo's Gifts: Indian-European Exchange in the Colonial Southeast. Philadelphia: University of Pennsylvania Press.

Hancock, Lambreth

I983 Hawaii Kai: The First 20 Years. Honolulu: The Rotary Club of Hawaii Kai.

Hanlon, David

I988 Upon a Stone Altar: A History of the Island of Pohnpei to I 890. Pacific Islands Monograph Series 5. Honolulu: Center for Pacific Islands Studies and University of Hawai'i Press.

I990 "The Pleasure of Speculation and Conjecture": Early Euro-American Visions of Nan Madol and Their Relevance to Post-Modern Archaeological Investigations. In Recent Advances in Micronesian Archaeology: Proceedings of the Micronesian Archaeology Conference Held on Guam from September 9 to I2, I987, edited by Rosalind L Hunter. Published as a special issue of Micronesica, Supplement 2, 99-II6.

I992 Sorcery, "Savage Memories," and the Edge of Commensurability for History in the Pacific. In Pacific Islands History: Journeys and Transformations, edited by Brij V Lal, I07-I 28. Canberra: Journal of Pacific History.

I999 Magellan's Chroniclers: American Anthropology's History in Micronesia. In American Anthropology in Micronesia: An Assessment, edited by Robert C Kiste and Mac Marshall, 53-79. Honolulu: University of Hawai'i Press.

2003 Beyond "the English Method of Tattooing": Decentering the Practice of History in Oceania. In Back to the Future: Decolonizing Pacific Studies, edited by Vilsoni Hereniko and Terence Wesley-Smith. Special issue of The Contemporary Pacific I 5:19-40.

20I4 A Different Historiography for "a handful of chickpeas flung over the sea": Approaching the Federated States of Micronesia's Deeper Past. Presentation for the symposium Pacific Futures: Past and Present, sponsored by the University of Sydney's Program on Race and Ethnicity in the Global South and the University of Otago's Centre for Research on Colonial Culture at the University of Otago, Dunedin, New Zealand, I9-2I June. 
Hau'ofa, Epeli

2008 We Are the Ocean: Selected Works. Honolulu: University of Hawai'i Press.

Howe, Kerry R

I979 Pacific Islands History in the I980s: New Directions or Monograph Myopia? Pacific Studies 3 (I): 8 I-90.

I992 The Future of Pacific Islands History: A Personal View. In Pacific Islands History: Journeys and Transformations, edited by Brij V Lal,

Igler, David 225-23I. Canberra: Journal of Pacific History.

20I3 The Great Ocean: Pacific Worlds from Captain Cook to the Gold Johannes, Robert Rush. New York: Oxford University Press.

I98 I Words of the Lagoon: Fishing and Marine Lore in the Palau District Jolly, Margaret of Micronesia. Berkeley: University of California Press.

200I On the Edge? Deserts, Oceans, Islands. The Contemporary Pacific I 3:4I 7-466.

2014 Horizons and Rifts in Conversation about Climate Change in Oceania. Presentation for the conference Pacific Futures: Past and Present sponsored by the University of Sydney's program on Race and Ethnicity in the Global South and the Centre for Research on Colonial Culture at the University of Otago, Dunedin, New Zealand, I9-2 I June.

Keesing, Roger M

I982 Kwaio Religion: The Living and the Dead in a Solomon Island Society. New York: Columbia University Press.

Kirch, Patrick Vinton

2000 On the Road of the Winds: An Archaeological History of the Pacific Islands before European Contact. Berkeley: University of California Press.

Kirsch, Stuart

2006 Reverse Anthropology: Indigenous Analysis of Social and Environmental Relations in New Guinea. Stanford: Stanford University Press.

Koselleck, Reinhart

2004 Modernity and the Planes of Historicity. In Futures Past: On the Semantics of Historical Time, translated and with an introduction by Keith Tribe, 9-25. New York: Columbia University Press.

Kupperman, Karen Ordahl

2000 Indians and English: Facing Off in Early America. Ithaca, NY: Cornell University Press. 
Lyons, Paul, and Ty P Kāwika Tengan

20I 5 Introduction: Pacific Currents. Special issue of American Quarterly $67(3): 545-574$.

Matsuda, Matt K

2012 Pacific Worlds: A History of Seas, Peoples, and Cultures. New York: Cambridge University Press.

Maunalua.net

20I 5 Exploring the History of Maunalua. http://www.maunalua.net/Aloha .html [accessed I 5 Dec 2015]

Mauricio, Rufino

I993 Ideological Bases for Power and Leadership on Pohnpei, Micronesia: Perspectives from Archaeology and Oral History. PhD dissertation, University of Oregon.

[2015] Ancient Religious and Political Development in Present day Kitti. Manuscript in the possession of the author.

Morgan, Philip D, and Jack P Greene

2009 Introduction. In Atlantic History: A Critical Appraisal, 3-3 I. New York: Oxford University Press.

Muckle, Adrian

20I 5 Review Forum: Pacific Histories: Ocean, Land, and People, edited by David Armitage and Alison Bashford. Journal of Pacific History $50(2): 229-240$.

Munro, Doug, and Brij V Lal, editors

2006 Texts and Contexts: Reflections in Pacific Islands Historiography. Honolulu: University of Hawai'i Press.

Neumann, Klaus

1992 Not the Way It Really Was: Constructing the Tolai Past. Pacific Islands Monograph Series ro. Honolulu: Center for Pacific Islands Studies and University of Hawai'i Press.

O’Reilly, William

2004 Genealogies of Atlantic History. Atlantic Studies I (I): 66-84.

Parmentier, Richard J

I987 The Sacred Remains: Myth, History, and Polity in Belau. Chicago: University of Chicago Press.

Pukui, Mary Kawena

I983 'Ōlelo No'eau: Hawaiian Proverbs and Poetical Sayings. Honolulu: Bishop University Press.

Rainbird, Paul

2004 The Archaeology of Micronesia. Cambridge World Archaeology Series. New York: Cambridge University Press. 
Rehg, Kenneth L, and Damian G Sohl

I979 Ponapean-English Dictionary. PALI Language Texts: Micronesia. Honolulu: The University Press of Hawaii.

Riesenberg, Saul H

I948 Magic and Medicine in Ponape. Southwestern Journal of Anthropology $4(4)$ : 406-429.

Rumsey, Alan

200I Introduction. In Emplaced Myth: Space, Narrative, and Knowledge in Aboriginal Australia and Papua New Guinea, edited by Alan Rumsey and James F Weiner, I-I 8. Honolulu: University of Hawai'i Press.

Salesa, Damon

2014 The Pacific in Indigenous Time. In Pacific Histories: Ocean, Land, People, edited by David Armitage and Alison Bashford, 3 I-52. New York: Palgrave Macmillan.

Schieffelin, Edward L, and Robert Crittenden, editors

I99I Like People You See in a Dream: First Contact in Six Papuan Societ-

Stilgoe, John R ies. Stanford: Stanford University Press.

I994 Alongshore. New Haven, ст: Yale University Press.

Stump, Jane Barr

I98 I Our Hawaii Kai: A History of Hawaii Kai and Maunalua. Honolulu: J B Stump.

Sweet, James H

$20 \mathrm{I}$ Domingos Álvares, African Healing, and the Intellectual History of the Atlantic World. Chapel Hill: University of North Carolina Press.

Tambiah, Stanley Jeyaraja

I990 Magic, Science, Religion, and the Space of Rationality. Cambridge, UK: Cambridge University Press.

Taylor, John Patrick

2008 The Other Side: Ways of Being and Place in Vanuatu. Pacific Islands Monograph Series 22. Honolulu: Center for Pacific Islands Studies and University of Hawai'i Press.

Teaiwa, Katerina Martina

2015 Consuming Ocean Island: Stories of People and Phosphate from Banaba. Bloomington: Indiana University Press.

Teaiwa, Teresia K

$200 \mathrm{I} \quad \mathrm{L}(\mathrm{o})$ osing the Edge. The Contemporary Pacific I 3:343-357.

2004 Mānoa Rain. In Pacific Places, Pacific Histories, edited by Brij V Lal, 2 I6-236. Honolulu: University of Hawai'i Press.

2006 On Analogies: Rethinking the Pacific in a Global Context. The Contemporary Pacific I0:7 I-87. 
2008 Globalizing and Gendered Forces: The Contemporary Militarization of Pacific/Oceania. In Gender and Globalization in Asia and the Pacific: Method, Practice, Theory, edited by Kathy E Ferguson and Monique Mironesco, 3 I 8-332. Honolulu: University of Hawai'i Press.

Tengan, Ty P Kāwika

2005 Unsettling Ethnography: Tales of an 'Ōiwi in the Anthropological Slot. Anthropological Forum I 5 (3): 247-256.

Tengan, Ty P Kāwika, and Lamakū Mikahala Roy

2014 "I Search for the Channel Made Fragrant by the Maile": Genealogies of Discontent and Hope. Association for Social Anthropology in Oceania 20I4 Distinguished Lecture. Oceania 84 (3):3 I 5-330.

Thomas, Keith

I97 I Religion and the Decline of Magic: Studies in Popular Beliefs in Sixteenth and Seventeenth Century England. London: Weidenfeld \& Nicolson.

Thompson, E P

I978 The Poverty of Theory and Other Essays. New York: Monthly Review Press.

Tobin, Jack A

2002 Stories from the Marshall Islands: Bwebwenato Jān Aelōn Kein. PALI Language Texts. Honolulu: University of Hawai'i Press.

Warrior, Robert, editor

20I 5 The World of Indigenous North America. New York: Routledge.

Warsh, Molly A, and Philip D Morgan, editors

2OI4 Early North America in Global Perspective. New York: Routledge.

Weaver, Jace

$20 \mathrm{I} 4$ The Red Atlantic: American Indigenes and the Making of the Modern World, I000-1927. Raleigh: University of North Carolina Press.

Zukas, Ale

2015 The History Guild Manifesto. Review of The History Manifesto, by Jo Guldi and David Armitage. H-Net Review (H-Socialisms). https://www.h-net.org/reviews/showpdf.php? $\mathrm{id}=42836$ [accessed 29 Dec 20I6]

\section{Abstract}

Pacific history has been rediscovered of late by those seeking to incorporate the region into more transnational, global, and world histories. There is much good to be derived from regional and comparative approaches that link Pacific pasts to larger historical processes and to the boundary-defying movement of peoples, 
goods, and ideas. Pacific history needs very much to be in conversation with historians and theorists from elsewhere. There is also the issue of recovery. Drawing inspiration from the works of Greg Dening, Vince Diaz, and others, I address the persisting need for the recovery of deeper Oceanic pasts that bear on our shared if unequal present-an effort made even more necessary by the generalizations and omissions that come with a globalizing approach to Islands' pasts. In this effort at recovery, I look to imagination, discursive flourish, indigenous knowledge, and Deep Time as integral methodologies that offer the possibility of transcending the conventions of historical research in the Pacific on a voyage that is ultimately about liberation.

KEYWORDS: Pacific, history, Oceania, indigenous studies, historicities, ethnography 